\title{
AIR TEMPERATURE AND PRECIPITATION AT WOLVERINE GLACIER, ALASKA; GLACIER GROWTH IN A WARMER, WETTER CLIMATE
}

\author{
by
}

L.R. Mayo and R.S. March

(U.S. Geological Survey, 800 Yukon Drive, Fairbanks, AK 99775-5150, U.S.A.)

\section{ABSTRACT}

Measurements at Wolverine Glacier, Alaska, from 1968 to 1988 indicate unsteady increases of air temperature and precipitation since the early 1970s. These increases were due almost entirely to changes in winter. Variations in annual temperature and precipitation at Wolverine Glacier and at Seward, a nearby climatological station at sea level, correlate positively with global temperature variations and are in general agreement with the changes at high latitudes predicted by five recent general atmospheric circulation models forced by anticipated rises of $\mathrm{CO}_{2}$.

A consequence of the air temperature and precipitation increases at Wolverine Glacier was a change to a generally positive mass balance after 1976. Although these observations in the coastal maritime climate of Alaska run against the common, oversimplified notion that in a warming climate glaciers will melt, causing sea level to rise, they are logical and easily understood when the sensitivity of the glacier to the seasonal distribution of the changes is considered. The observed seasonal changes at Wolverine Glacier also are in agreement with global climate models. Snow precipitation and glacier accumulation increased, but at the same time warming affected only these those temperatures below about $-5^{\circ} \mathrm{C}$, and melting was not altered. The extent of this response is not well known, but the process may be taking place in other important glacierized regions.

\section{INTRODUCTION}

Glaciologic, climatologic, and hydrologic research began at Wolverine Glacier in 1966 as part of the International Hydrological Decade program. The glacier is located in the maritime climate of southern Alaska $\left(60^{\circ} 23^{\prime} \mathrm{N} ., 148^{\circ} 55^{\prime} \mathrm{W}\right.$.) near the Pacific Ocean, Gulf of Alaska. Mayo and Trabant (1984) discovered that Wolverine Glacier began growing following the summer of 1976 and, on the basis of

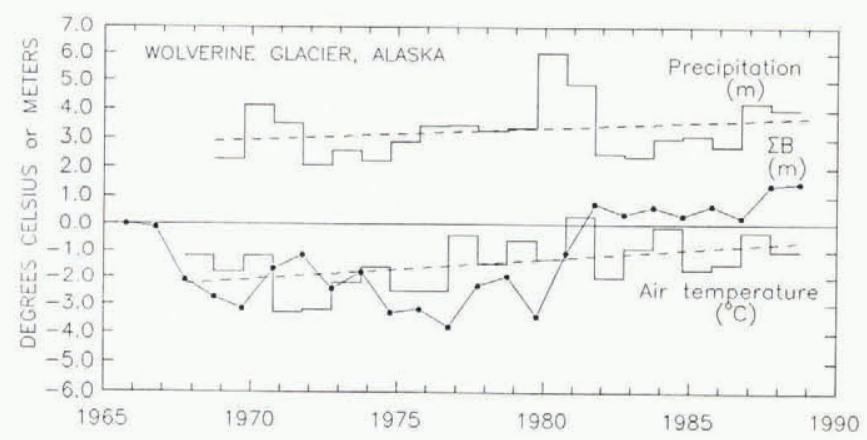

Fig. 1. Annual precipitation averaged over the drainage basin, mean annual air temperature at $900 \mathrm{~m}$ altitude, and cumulative glacier mass balance, $\Sigma \mathrm{B}$, at Wolverine Glacier, Alaska; for measurement years, October 1 to September 30. Dashed lines are linear regressions of the climate data. observed processes, made a prediction of continued glacier growth if the climate there warms $5^{\circ} \mathrm{C}$ or less. Haeberli and others (1989) have recognized that Wolverine and other glaciers in coastal mountain regions, such as those of Norway, show evidence of recent growth. Responses to any global temperature rise are expected to show up first at high latitudes (Hall, 1988).

In this paper we examine the anual and seasonal variations of air temperature and precipitation at Wolverine Glacier during this period of change. The terms "winter" and "summer" refer respectively to the accumulation and ablation seasons.

Air temperature, precipitation, and glacier mass balance can be highly variable in both time and space. Trends can be detected if some of the noise in the record is ignored by first taking averages in space over the glacier surface or drainage basin and averages in time over months and years, and then looking for systematic changes. Most of the trends we find are imperfect and have exceptions.

\section{AIR TEMPERATURE AND PRECIPITATION}

An air temperature and precipitation gage at $990 \mathrm{~m}$ altitude in the Wolverine Glacier drainage basin is located on a ridge $500 \mathrm{~m}$ from the glacier edge and about $100 \mathrm{~m}$ lower than the glacier's average mass balance equilibriumline altitude, ELA. It has provided climate information from May 1967 to September 1988 and is the only climate station operated year-round near the general ELA of glaciers in the Kenai, Chugach, and St. Elias Mountains of southern Alaska.

The average annual air temperature at the site was $-1.5^{\circ} \mathrm{C}$ from October 1967 through September 1988. Mean annual precipitation for the drainage basin was about $3.3 \mathrm{~m}$ from October 1968 through September 1988. For comparison, the average air temperature near sea level at Seward, $40 \mathrm{~km}$ southwest of Wolverine Glacier, was $+4.2^{\circ} \mathrm{C}$ and the average annual pecipitation was $1.77 \mathrm{~m}$ (National Weather Service, 1907-1988). Basin-average precipitation at Wolverine Glacier was determined from measurements of river discharge at the terminus, glacier mass balance, and the precipitation gage catch. Wind effects on the gage, and its location in a relatively dry area of the basin, combine to reduce its catch to approximately $1 / 3$ of the basin average rain and snowfall.

Annual precipitation and air temperature (Fig. 1) at Wolverine Glacier show unsteady increases to 1988 from minima in 1972 (P) and 1971 (T). The average rates of temperature increase for the period of record starting in 1967 was $0.76^{\circ} \mathrm{C}$ per decade. The annual precipitation increase since 1968 was $0.42 \mathrm{~m}$ per decade. The F-Ratio statistic indicates that the confidence level at which the regression slope is significant is $98 \%$ for air temperature, but only $65 \%$ for precipitation.

Both precipitation and air temperature show seasonal patterns (Fig. 2). Air temperature variations are dominated by the annual cycle, with about seven months each year being colder than $0^{\circ} \mathrm{C}$. By comparison, precipitation had a relatively weak seasonal pattern that was frequently interrupted by strong precipitation anomalies. On average 


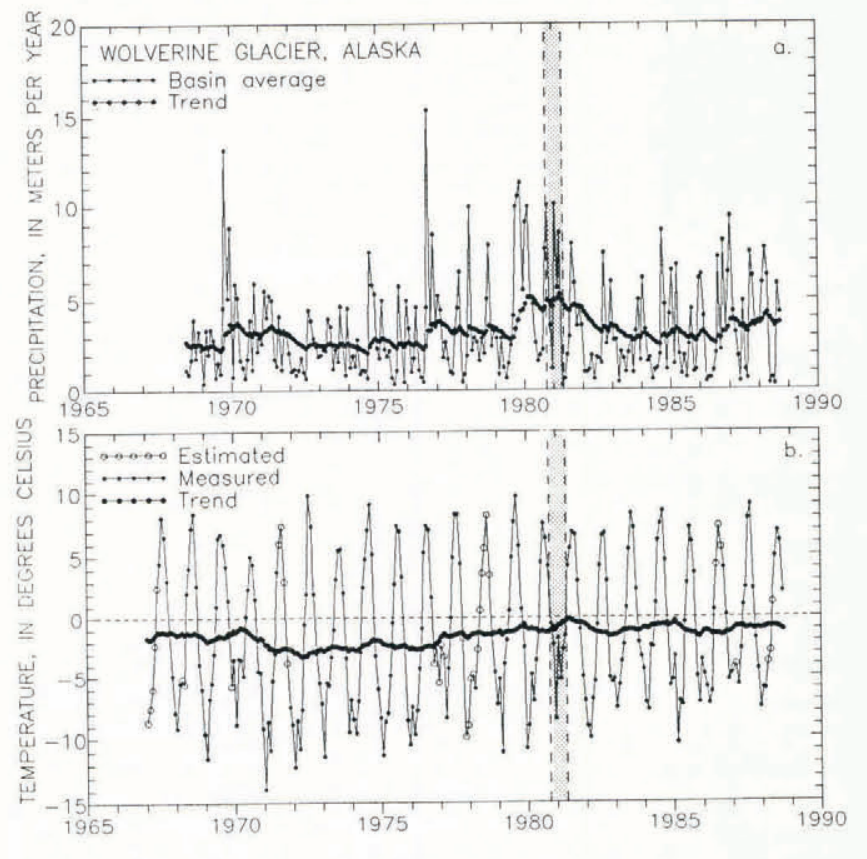

Fig. 2a. Monthly precipitation at Wolverine Glacier basin; recorded gage catch $\times 3$ converted to annual equivalent rates. (b). Air temperature at $990 \mathrm{~m}$ altitude at Wolverine Glacier (dots); estimates (circles) based on data from Seward, Alaska (National Weather Service (1967-1988). Trends calculated using a 10-month half-life exponential weighting function (Mayo and Trabant, 1986). Shaded area indicates an example of a winter with warm temperatures and high precipitation.

June was the driest month with about $120 \mathrm{~mm}$ basin precipitation, September the wettest with about $460 \mathrm{~mm}$.

The onset, duration, and strength of anomalies and trends in temperature and precipitation can be determined by weighting the time series data using an exponential function and progressively averaging the results (Mayo and Trabant, 1986). The procedure uses data preceding a given date, but no values after it; so it can be calculated using current data, is not affected by any changes in the future, and shows the onset of anomalies and trends at the time they begin. The duration and cumulative effects of anomalies are indicated by a continuously rising or falling trend line for the full period of each anomaly. The time series weighted mean was calculated by:

$$
\bar{X}_{t}=\frac{\sum_{i=1}^{t} 0.5^{(t-i) / p_{\mathrm{D}_{i}}}}{\sum_{i=1}^{t} 0.65^{(t-i) / p}},
$$

where $\bar{X}_{t}$ is the $t$ th weighted mean value of the series, $i$ is the index of summation, $t$ is the sequence number in the time series, $p$ is the half-life period, arbitrarily 10 months in this case, and $D$ is the measured or estimated value.

The precipitation trend (Fig. 2a) was calculated from values of basin precipitation, gage catch times three, and is expressed in terms of the equivalent annual precipitation rate. To obtain the air temperature trend (Fig. 2b), we subtracted the long-term means for each month from the monthly temperatures to remove information about the annual cycle, added the mean annual temperature, $-1.5^{\circ} \mathrm{C}$, so that the trend line varies about the average temperature, and then calculated the weighted mean value (Equation 1).

In general, the climate at Wolverine Glacier (Fig. 2) was warmer and wetter after September 1976 than before that time. Periods of anomalously high precipitation and air temperature tend to begin relatively abruptly, last for several months, and take place during winter. One example of a relatively warm winter with high precipitation is the winter of $1980-81$, which is identified by shading on Figure 2.
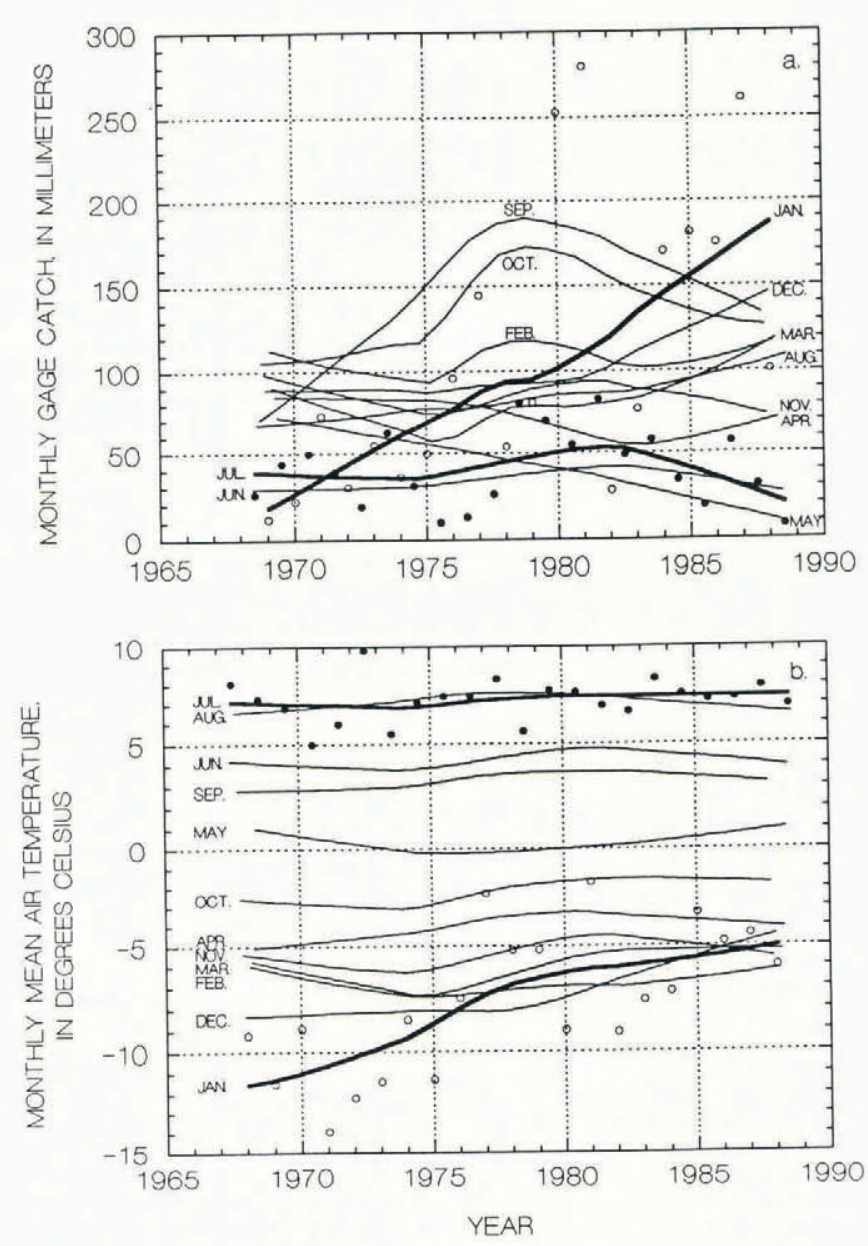

Fig. 3. Trends of monthly precipitation gage catch (a), and monthly mean air temperature (b), at Wolverine Glacier calculated using the lowess smoothing function (Cleveland, 1979). Data shown as examples only for January (circles) and July (dots).

Another method of examining the seasonality of climatic variation is to analyze the time trend of precipitation and air temperature for each month independently (Fig. 3). Both varied more in winter than in summer. Precipitation increased primarily in December and January. Months in which average temperatures were warmer than about $-5^{\circ} \mathrm{C}$ showed no significant trends, but temperatures during the cold months of December and January warmed appreciably. These are the same two months in which precipitation increased the most.

\section{CLIMATIC VARIATIONS AT OTHER SITES}

The seasonal pattern of temperature and precipitation described by Diaz (1986) at sea level in western Canada and southern Alaska are the same as those at Wolverine Glacier (Fig. 4). The pattern consists of positive correlations of temperature and precipitation in winter, and negative correlations in summer. The correlations at Wolverine Glacier are not strong, yet they indicate that warming during winter is associated with storms that bring both moisture and warm air to the area. From May to August the reverse is true, indicating that fair-weather solar radiation and advection of warm, dry air are the main sources of atmospheric heating.

Air temperatures at Wolverine Glacier and Seward show a tendency to correlate with global temperature changes calculated by Hansen and Lebedeff (1987, 1988) (Fig. 5). The amplitudes of annual air temperature variations at Wolverine Glacier and Seward were about six times greater than global temperature changes, and the warming during the past two decades at the Alaskan sites was about four times greater than the global temperature increase. 


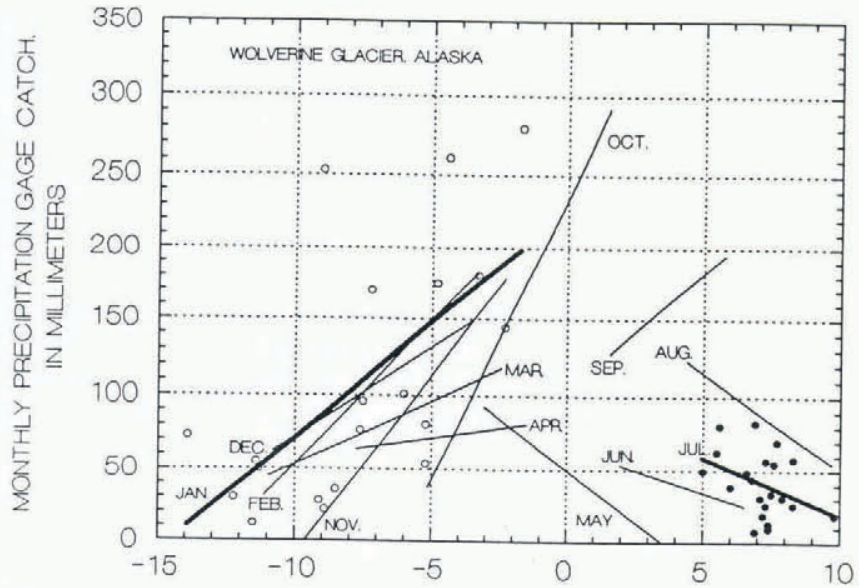

MONTHLY MEAN AIR TEMPERATURE, IN DEGREES CELSIUS

Fig, 4. Linear regressions of monthly precipitation gage catch as a function of air temperatures at Wolverine Glacier. Data shown as examples only for January (circles) and July (dots).

Precipitation at Wolverine Glacier and Seward also shows a tendency to correlate with global air temperature changes (Fig. 6). This suggests that the intensity of cyclone activity and input of snow and rain to the glaciers in southern Alaska is responsive, through atmospheric circulation, to changes in the global temperature.
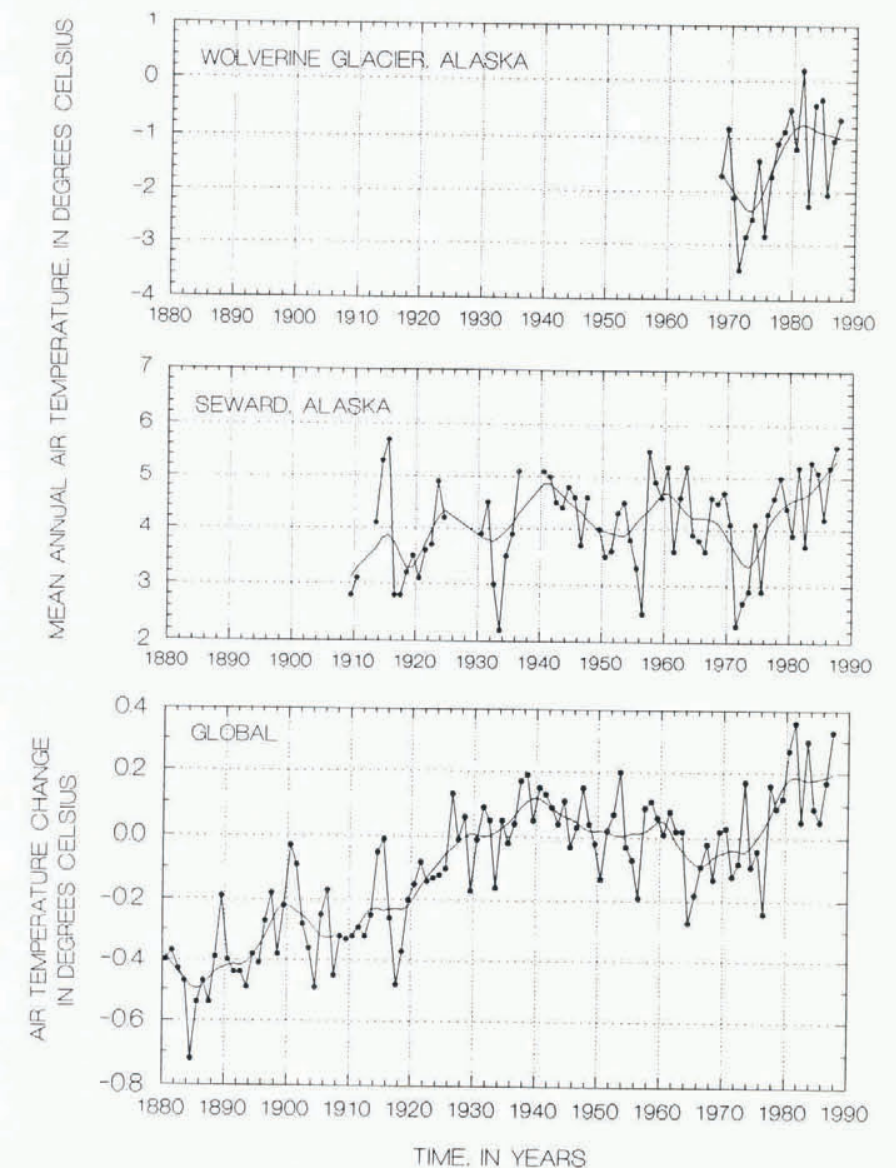

Fig. 5. Annual (calendar year) average air temperatures at Wolverine Glacier (authors), and Seward, Alaska (National Weather Service, 1907-1988), and global change of air temperature (Hansen and Lebedeff, 1987 and 1988). Trends calculated using the lowess smoothing function (Cleveland, 1979).

\section{MASS BALANCE}

Wolverine Glacier increased in mass by an amount equal to about $6 \mathrm{~m}$ of ice averaged over its surface from 1976 through 1988 following a decade of generally negative mass balance (Fig. 1). The change was not simple. During the period of shrinkage, 1966-76, the mass balance in 1970 was positive; and during the decade of growth, 1977-88, 1979, was negative.

The cumulative change, expressed in meters of water equivalent averaged over the glacier's surface from 1965 (Fig. 1), is the summation of annual mass balances at the end of September each year. It is based on glacier mass balance gradients determined from standard glaciological observations of snow, firn, and ice (Østrem and Stanley, 1969; Mayo and others, 1972) at three monitoring sites (sites A, B, and C; Tangborn and others, 1977). This information was modified from that published earlier (Mayo and Trabant, 1984). New time series information has been added and an adjustment (unpublished) was applied to the entire record which is based on an independent volume change measurement of the glacier from 1974 in 1985 (Mayo and others, 1985). The volume change measurement verified that growth of Wolverine Glacier had taken place, but indicated a smaller net volume increase than had been calculated earlier.

\section{CLIMATE AND MASS BALANCE}

Shrinkage of Wolverine Glacier took place during years with cold, dry winters and warm summers, such as 1972 and 1979. Growth of the glacier in 1970, 1977, 1980, 1981, 1987 , and 1988 was caused primarily by large amounts of
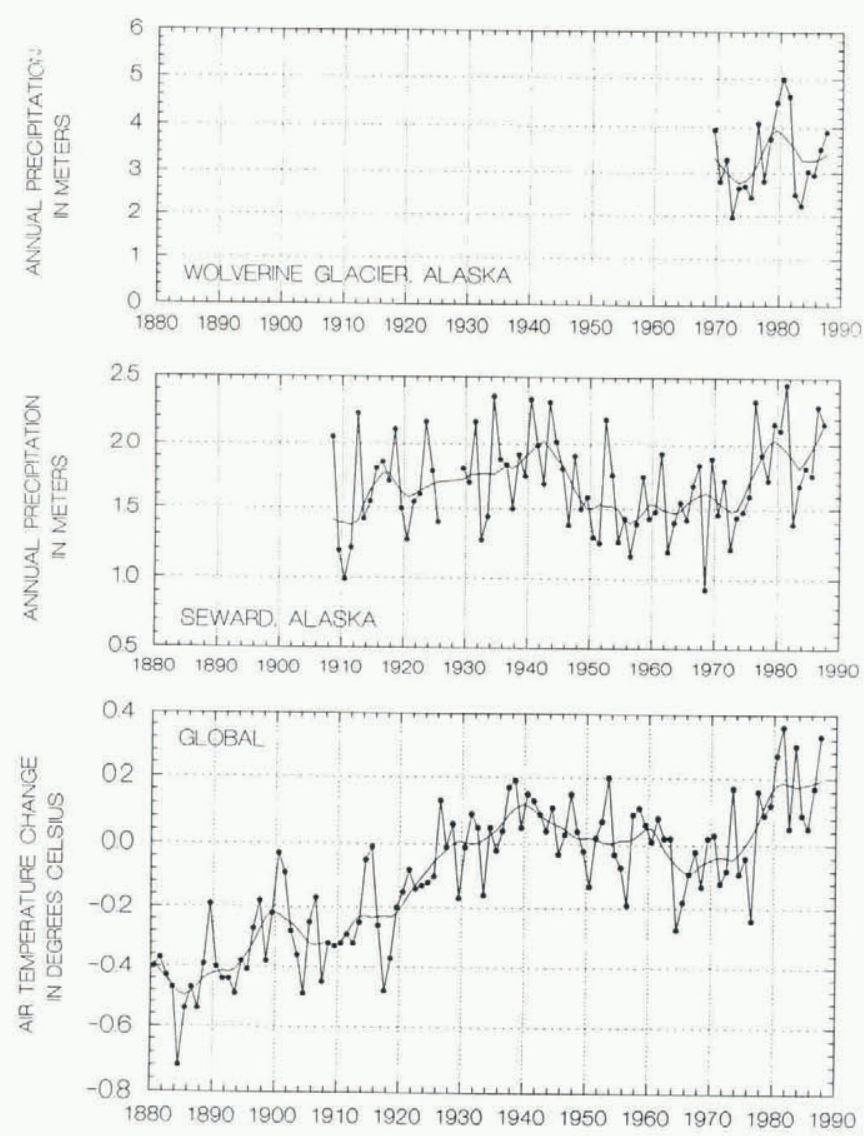

TIME. IN YEARS

Fig. 6. Annual (calendar year) precipitation at Wolverine Glacier (authors); Seward, Alaska (National Weather Service, 1907-1987); and global air temperature change (Hansen and Lebedeff, 1987 and 1988). Trends calculated using the lowess smoothing function (Cleveland, 1979). 
snow accumulation. The 1981 accumulation season is identified on Figure 2 to illustrate an occurrence of high snow accumulation taking place at the same time as unusually warm winter air temperatures.

Intense storms beginning in late August of 1976 initiated the general period of growth of Wolverine Glacier. After August 1976, precipitation rates were generally greater than during the preceding decade and tended to increase principally in winter (Figs. 2 and 3). At the same time, air temperatures during the winters were higher than during the earlier period. However, winter air temperatures rema....d below freezing, so the snow was not converted to rain. Temperatures during summer showed little sign of increasing. For these reasons the glacier's accumulation increased but its ablation changed little and the glacier grew as a consequence.

\section{RELATION TO RESULTS OF ATMOSPHERIC CIRCULATION MODELS}

Five recent studies on the effects of increasing atmospheric $\mathrm{CO}_{2}$ on global climate have been reveiwed by Mitchell (1989). All models included orographic effects, changes in cloud cover, the season cycle, and a mixed-layer ocean. The models show the following results of a doubling of $\mathrm{CO}_{2}$ :

1. Warming is most pronounced at high latitudes.

2. This warming is most pronounced in winter.

3. There is a general increase in precipitation at high latitudes.

4. This precipitation increase is most pronounced in winter.

5. The globally-averaged hydrologic cycle is intensified.

All of these predicted results are in agreement with changes indentified in the climate record at Wolverine Glacier. While this agreement cannot be interpreted to mean that increasing $\mathrm{CO}_{2}$ was the cause of the recent growth of Wolverine Glacier, they do indicate that the climate and glaciers of southern Alaska are to some degree responsive to global heating and cooling by the atmospheric circulation processes described by the models.

\section{CONCLUSIONS}

It is stated frequently that climatic warming will produce increases in melting of glaciers and, consequently, a rise of sea level. Observations at Wolverine Glacier, Alaska, indicate that this is an oversimplification and that other important possibilities exist. In this sub-arctic maritime climate zone of Alaska, the greatest amount of climatic variability from 1968 to 1988 , including warming, took place primarily during winter, when snow was accumulating and air temperatures were significantly colder than $0^{\circ} \mathrm{C}$.

The result of the relatively minor climatic warming and increase in precipitation over the two-decade period was to produce an increase in glacier accumulation, no commensurate increase in melting, and a shift from generally negative to positive glacier mass balance. This is a good illustration of the concept that glaciers can be sensitive indicators of climate. It also shows that interrelations of climate and glaciers are far from simple. Regarding future changes of glacier regimes in Alaska and elsewhere, we conclude that predictions of precipitation and snow accumulation are just as important as predictions of summer temperatures and melting.

Global climate models (Mitchell, 1989) have shown that temperatures and precipitation may rise more in high latitude areas than in low latitude areas in response to an increase in atmospheric $\mathrm{CO}_{2}$. The models also show that temperature increases at high latitudes tend to affect winter much more than summer. Because these models predict that the type of changes found in Alaska are expected to be widespread at high latitudes, the complex glacier mass balance responses found at Wolverine Glacier may also be taking place in other important glacierized regions, but the distribution is not known well.

\section{ACKNOWLEDGEMENTS}

This paper was reviewed by R.M. Krimmel, U.S. Geological Survey, W.F. Weeks and G.E. Weller, Geophysical Institute, University of Alaska Fairbanks; and B. Wold, Norwegian Water Resources and Energy Administration. Their helpful comments strengthened the manuscript and are appreciated.

\section{REFERENCES}

Cleveland, W.S. 1979. Robust locally weighted regression and smoothing scatterplots. J. Am. Stat. Assoc., 74(368), 829-836.

Diaz, H.F. 1986. An analysis of twentieth century climate fluctuations in northern North America. J. Climate Appl. Meteorol., 25(11), 1625-1657.

Haeberli, W., P. Müller, P. Alean, and H. Bosch. 1989. Glacier changes following the little ice age - a survey of the international data basis and its perspectives. In Oerlemans, J., ed. Glacier fluctuations and climatic change. Dordrecht, etc., Kluwer Academic Publishers, 77-101.

Hall, D.K. 1988. Assessment of polar climate change using satellite technology. Rev. Geophys., 26, 26-39.

Hansen, J. and S. Lebedeff. 1987. Global trends of measured surface air temperature. J. Geophys. Res., 92(D11), 13,345-13,372.

Hansen, J. and S. Lebedeff. 1988. Global surface air temperatures update through 1987. Geophys. Res. Lett., 15(4), 323-326.

Mayo, L.R. and D.C. Trabant. 1984. Observed and predicted effects of climate change on Wolverine Glacier, southern Alaska. In McBeath, J.H., G.P. Juday, G. Weller, and M. Murray, eds. The potential effects of carbon dioxideinduced climate change in Alaska. Fairbanks, AK, University of Alaska, 114-123. (Miscellaneous Publications 83-1.)

Mayo, L.R. and D.C. Trabant. 1986. Recent growth of Gulkana Glacier, Alaska Range, and its relation to glacier-fed river runoff. U.S. Geol. Surv. Water-Supply Pap. 2290, 91-99.

Mayo, L.R., M.F. Meier, and W.V. Tangborn. 1972. A system to combine stratigraphic and annual mass-balance systems: a contribution to the International Hydrological Decade. J. Glaciol., 11(61), 3-14.

Mayo, L.R., R.S. March, and D.C. Trabant. 1985. Growth of Wolverine Glacier, Alaska; determined from surface altitude measurements, 1974-1985. In Dwight, L.P., ed. Resolving Alaska's water resources conflicts. Fairbanks, AK, University of Alaska. Institute of Water Resources, 113-121. (Report IWR-108.)

Mitchell, J.F.B. 1989. The "greenhouse" effect and climate change. Rev. Geophys., 27(1), 115-139.

National Weather Service. 1907-1988. Climatological data. Annual summary, Alaska. Rockville, MD, National Oceanic and Atmospheric Administration.

Østrem, G. and A. Stanley. 1969. Glacier mass balance measurements; a manual for field and office work. Ottawa, Canadian Department of Energy, Mines and Resources. Oslo, Norwegian Water Resources and Electricity Board.

Tangborn, W.V., L.R. Mayo, D.R. Scully, and R.M. Krimmel. 1977. Combined ice and water balances of Maclure Glacier, California, South Cascade Glacier, Washington, and Wolverine and Gulkana glaciers, Alaska, 1967 Hydrologic Year. U.S. Geol. Surv. Prof. Pap. 715-B. 